\title{
PENGARUH UKURAN PERUSAHAAN, PROFITABILITAS, LEVERAGE, DAN KUALITAS AUDIT TERHADAP PENGHINDARAN PAJAK PADA PERUSAHAAN MANUFAKTUR PERIODE 2016-2018
}

\author{
Tagor Darius Sidauruk, SE., M.Si \\ Siti Nur Fadilah \\ tagor.darius@yahoo.com
}

\section{Fakultas Ekonomi dan Bisnis - Program Studi Akuntansi Universitas Satya Negara Indonesia}

\begin{abstract}
ABSTRAK
Perusahaan berusaha menekan biaya pajaknya demi mendapatkan laba yang lebih tinggi. Terdapat beberapa faktor yang mempengaruhi penghindaran pajak dalam suatu perusahaan. Penelitian ini bertujuan untuk mengetahui apakah ukuran perusahaan, profitabilitas, leverage, dan kualitas audit berpengaruh terhadap penghindaran pajak.

Populasi penelitian ini adalah perusahaan manufaktur yang terdaftar di Bursa Efek Indonesia (BEI) pada tahun 2016-2018 yaitu sebanyak 153 perusahaan. Sampel penelitian berjumlah 72 perusahaan atau 216 data observasi yang dipilih dengan metode purposive sampling. Data yang dipergunakan adalah data sekunder yang diperoleh dari Bursa Efek Indonesia (BEI). Metode analisis data dalam penelitian ini yaitu Analisis Statistik Deskriptif, analisis Regresi Logistik.

Hasil penelitian menunjukkan bahwa ukuran perusahaan, leverage, dan kualitas audit tidak berpengaruh terhadap penghindaran pajak. Sedangkan profitabilitas berpengaruh positif terhadap penghindaran pajak.
\end{abstract}

Kata Kunci: Ukuran Perusahaan, Profitabilitas, Leverage, Kualitas Audit, dan Penghindaran Pajak 


\section{PENDAHULUAN}

\section{Latar Belakang}

Sektor pajak merupakan salah satu penerimaan negara yang berkontribusi paling besar dalam menunjang pembangunan dan pembiayaan nasional serta mewujudkan kemandirian suatu negara. Pemerintah pastinya menginginkan penerimaan dari sektor pajak yang selalu meningkat tiap tahunnya. Usaha pemerintah untuk mengoptimalkan penerimaan sektor pajak dilakukan melalui usaha intensifikasi dan ekstensifikasi penerimaan pajak.

Perusahaan merupakan salah satu wajib pajak yang memberikan kontribusi terbesar dalam penerimaan pajak suatu negara, namun ternyata banyak perusahaan yang menganggap bahwa pajak merupakan komponen beban dalam laporan keuangan yang dapat mengurangi laba bersih mereka. Masih banyaknya wajib pajak dalam hal ini perusahaan yang berusaha untuk membayar pajak serendah mungkin dengan cara melakukan perencanaan pajak sehingga mengakibatkan menurunnya penerimaan negara dari pajak tersebut. Menurut, Suandy (2013) mengatakan bahwa pada umumnya para pelaku usaha (perusahaan) mengidentikkan pembayaran pajak sebagai beban yang akan menurunkan laba setelah pajak, tingkat pengembalian, dan arus kas.

Penghindaran pajak merupakan usaha mengurangi hutang yang bersifat legal sedangkan penggelapan pajak (Tax evasion) adalah usaha untuk mengurangi hutang pajak yang bersifat tidak legal. penghindaran pajak merupakan hal yang tidak diinginkan bagi pemerintah namun disisi lain tindakan tersebut tergolong dalam tindakan legal dan tidak melanggar hukum karena metode dan teknik yang digunakan adalah dengan memanfaatkan kelemahan (grey area) yang terdapat dalam undang-undang dan peraturan perpajakan itu sendiri, sehingga dalam hal ini Direktorat Jenderal Pajak tidak dapat melakukan penuntutan secara hukum kepada para pelaku tindakan penghindaran pajak. jumlah kasus tindakan tax avoidance yang terjadi di Indonesia masih cukup banyak sehingga hal tersebut berdampak pada berkurangnya penerimaan pajak. Fenomena kasus penghindaran pajak pada tahun 2014 Direktorat jenderal Pajak telah menyelidiki kasus penghindaran pajak oleh PT. Coca Cola Indonesia (CCI) diduga mengakali pajak sehingga menimbulkan kekurangan pembayaran pajak senilai Rp. 49,24 miliar.

Ukuran perusahaan sebagai skala atau nilai yang dapat mengklasifikasikan suatu perusahaan ke dalam kategori besar atau kecil berdasarkan total aset. Tahap kedewasaan perusahaan ditentukan berdasarkan total aset, semakin besar total aset menunjukkan bahwa perusahaan memiliki prospek baik dalam jangka waktu yang relatif panjang. Dengan besarnya total aset perusahaan tentunya akan cenderung mendorong perusahaan untuk melakukan praktik penghindaran pajak (Deddy, 2016). Namun perusahaan besar yang sudah go public tentunya akan melihat dari sisi publik apabila perusahaan melakukan praktik penghindaran pajak dan diketahui oleh fiskus tentunya ini akan membuat citra buruk perusahaan dimata publik dan mengurangi rasa percaya publik atas perusahaan tersebut. Ida Ayu Rosa Dewinta dan Putu Ery Setiawan (2016) dalam penelitiannya membuktikan bahwa ukuran perusahaan berpengaruh terhadap penghindaran pajak. Sementara penelitian Annisa (2017) menyatakan bahwa ukuran perusahaan tidak berpengaruh signifikan terhadap penghindaran pajak. 
Profitabilitas merupakan gambaran kinerja keuangan perusahaan dalam menghasilkan laba dari pengelolaan aset yang dikenal dengan Return On Assets (ROA). Profitabilitas yang tinggi menunjukkan bahwa perusahaan mampu mendapatkan laba yang maksimal. Semakin tinggi laba perusahaan maka semakin tinggi beban pajaknya. Dalam penelitian yang dilakukan oleh Ida Ayu Rosa Dewinta dan Putu Ery Setiawan (2016) menemukan bahwa profitabilitas berpengaruh secara negatif terhadap penghindaran pajak. Sedangkan menurut Deddy Dyas Cahyono (2016) menemukan bahwa profitabilitas tidak berpengaruh terhadap penghindaran pajak.

Leverage merupakan rasio yang mengukur seberapa besar perusahaan dibiayai dengan hutang. Suatu perusahaan yang memiliki tingkat leverage yang tinggi menunjukkan perusahaan tersebut bergantung pada hutang. Dengan adanya hutang akan menimbulkan beban tetap yaitu bunga, semakin perusahaan bergantung pada hutang maka beban hutang yang dibayarkan juga semakin besar. Beban hutang yang semakin tinggi akan memberikan pengaruh berkurangnya jumlah beban pajak perusahaan. Hasil penelitian Deddy Dyas Cahyono (2016) menunjukkan bahwa leverage tidak memiliki pengaruh yang signifikan terhadap penghindaran pajak. Sedangkan Annisa (2017) mengungkapkan bahwa leverage berpengaruh positif terhadap tax avoidance.

Kualitas audit adalah terjadinya segala kemungkinan saat auditor mengaudit laporan keuangan klien dan menemukan pelanggan atau kesalahan yang terjadi dan melaporkannya dalam laporan keuangan. Laporan keuangan yang diaudit oleh KAP The Big Four lebih berkualitas sehingga menampilkan nilai perusahaan yang sebenarnya, oleh karena itu diduga perusahaan yang diaudit oleh KAP The Big Four memiliki tingkat kecurangan pajak yang lebih rendah dibandingkan oleh perusahaan yang diaudit oleh KAP Non The Big Four. Jika nominal pajak yang dibayar terlalu tinggi biasanya akan memaksa perusahaan untuk melakukan penggelapan pajak, maka semakin berkualitas audit suatu perusahaan, maka perusahaan tersebut cenderung tidak melakukan manipulasi laba untuk kepentingan perpajakan. Arry Eksandy (2017) mengatakan bahwa kualitas audit berpengaruh positif terhadap penghindaran pajak. Sedangkan Fitri Darmayanti dan Tridahus Susanto (2015) mengatakan bahwa kualitas audit tidak berpengaruh terhadap penghindaran pajak.

Berdasarkan uraian di atas, peneliti bermaksud untuk melakukan penelitian yang berjudul: "Pengaruh Ukuran Perusahaan, Profitabilitas, Leverage, dan Kualitas Audit Terhadap Penghindaran Pajak pada perusahaan Manufaktur periode 2016-2018”.

\section{Rumusan Masalah}

Berdasarkan latar belakang di atas, maka perumusan masalah dalam penelitian ini adalah sebagai berikut :

1. Apakah ukuran perusahaan berpengaruh terhadap penghindaran pajak?

2. Apakah profitabilitas berpengaruh terhadap penghindaran pajak?

3. Apakah leverage berpengaruh terhadap penghindaran pajak?

4. Apakah kualitas audit berpengaruh terhadap penghindaran pajak?

\section{Tujuan Penelitian}

1. Untuk mengetahui pengaruh ukuran perusahaan terhadap penghindaran pajak. 
2. Untuk mengetahui pengaruh Profitabilitas terhadap penghindaran pajak.

3. Untuk mengetahui pengaruh Leverage terhadap penghindaran pajak.

4. Untuk mengetahui kualitas audit terhadap penghindaran pajak.

\section{LANDASAN TEORI}

\section{Penghindaran Pajak}

Menurut Undang-Undang Nomor 16 Tahun 2009 tentang Ketentuan Umum Perpajakan, pajak adalah kontribusi wajib kepada negara yang terutang oleh orang pribadi ataupun badan yang bersifat memaksa berdasarkan undang-undang dengan tidak mendapatkan imbalan secara langsung dan digunakan untuk keperluan negara bagi sebesar-besarnya kemakmuran rakyat.

Menurut Pohan (2013) manajemen pajak adalah usaha yang dilakukan tax manager agar hal-hal yang berhubungan dengan perpajakan dapat dikelola dengan baik, efisien dan ekonomis, sehingga memberi kontribusi maksimal bagi perusahaan. Fungsi-fungsi manajemen pajak adalah perencanaan pajak (tax planning), pelaksanaan kewajiban perpajakan (tax implementation), pengendalian pajak (tax control). Perencanaan pajak merupakan bagian dari manajemen perpajakan serta tahap awal untuk melakukan analisis secara sistematis berbagai alternatif perlakuan perpajakan dengan tujuan untuk mencapai pemenuhan kewajiban perpajakan minimum. Menurut Pohan (2013) strategi yang dapat ditempuh untuk mengefisiensikan beban pajak secara legal yaitu: (a) Penghematan pajak, (b) Penghindaran pajak atau tax avoidance, (c) Mengoptimalkan kredit pajak yang diperkenankan, (d) Menghindari pemeriksaan pajak dengan cara menghindari lebih bayar, dan (e) Menghindari pelanggaran pajak terhadap peraturan yang berlaku.

Menurut Mohammad Zain (2007) penghindaran pajak (Tax avoidance) adalah suatu tindakan yang benar-benar legal agar terhindar dari konsekuensi pengenaan pajak yang tidak dikehendaki, dalam hal ini sama sekali tidak ada suatu pelanggaran hukum dalam ketentuan peraturan perundang-undangan perpajakan yang dilakukan dan malah akan diperoleh penghematan pajak sehingga terhindar dari pengenaan pajak yang lebih besar atau mungkin sama sekali tidak kena pajak. Menurut Pohan (2013) penghindaran pajak merupakan hal yang tidak diinginkan bagi pemerintah namun disisi lain tindakan tersebut tergolong dalam tindakan secara legal, aman bagi wajib pajak dan tidak melanggar hukum, di mana metode dan teknik yang digunakan cenderung dengan memanfaatkan kelemahan (grey area) yang terdapat dalam undang-undang dan peraturan perpajakan itu sendiri untuk memperkecil jumlah pajak yang terutang. Penghindaran pajak bukannya bebas biaya. Beberapa biaya yang harus ditanggung yaitu pengorbanan waktu dan tenaga untuk melakukan penghindaran pajak, dan adanya risiko jika penghindaran pajak terungkap. Risiko tersebut adalah bunga dan denda; dan kehilangan reputasi perusahaan yang berakibat buruk untuk keberlangsungan usaha jangka panjang perusahaan.

Penghindaran pajak dapat diukur dengan menggunakan Cash Effective Tax Ratio (CETR). Cash Effective Tax Rate (CETR) yaitu kas yang dikeluarkan untuk pembayaran pajak dibagi dengan laba sebelum pajak. Perusahaan dikategorikan melakukan penghindaran pajak apabila Cash Effective Tax Rate (CETR) kurang 
dari $25 \%$ dan dikategorikan tidak melakukan penghindaran pajak apabila Cash Effective Tax Rate (CETR) lebih dari 25\% atau mendekati tarif pajak.

\section{Ukuran Perusahaan}

Menurut (Jogiyanto, 2013) ukuran perusahaan adalah besar kecilnya perusahaan yang dapat diukur dengan nilai total aset atau besar harta perusahaan dengan menggunakan perhitungan nilai natural log (Ln) total aset. Menurut Agnes Sawir (2012) ukuran perusahaan adalah ukuran yang dapat menentukan tingkat kemudahan perusahaan memperoleh dana dari pasar modal. Menurut Hormati (2009) dalam Yudi Mufti Prawira (2016) ukuran perusahaan adalah skala atau nilai yang dapat menunjukkan suatu perusahaan ke dalam kategori besar atau kecil berdasarkan total aset, log size, dan sebagainya.

Ukuran perusahaan adalah suatu skala yang dapat mengklasifikasikan perusahaan menjadi perusahaan besar dan kecil menurut berbagai cara seperti total aktiva atau total asset perusahaan, nilai pasar saham, rata-rata tingkat penjualan, dan jumlah penjualan. Perusahaan yang tergolong besar akan memiliki sumber daya yang besar salah satunya sumber daya manusia yang ahli dibidang perpajakan. Maka dari itu perusahaan besar cenderung melakukan praktik penghindaran pajak karena perusahaan besar memiliki sumber daya manusia yang ahli sangat dibutuhkan guna menekan beban pajak yang harus dibayarkan perusahaan (Yudi Mufti Prawira, 2016).

Ukuran perusahaan bisa diukur dengan menggunakan total aset, pendapatan atau modal dari perusahaan tersebut. Salah satu tolak ukur yang menunjukkan besar kecilnya perusahaan adalah ukuran aktiva dari perusahaan tersebut. Perusahaan yang memiliki total aset besar menunjukkan bahwa perusahaan tersebut telah mencapai tahap kedewasaan, dimana dalam tahap ini arus kas perusahaan sudah positif dan dianggap memiliki prospek yang baik dalam jangka waktu yang relatif stabil dan lebih mampu menghasilkan laba dibandingkan perusahaan dengan total aset yang kecil.

Menurut (Jogiyanto, 2013) pengukuran ukuran perusahaan dapat dihitung dengan rumus sebagai yaitu: Ukuran Perusahaan = Ln (Total Aset). Ln (total aset) dinilai lebih baik karena ukuran perusahaan ini memiliki tingkat kestabilan yang lebih. Tujuan pengguna Ln (Total Aset) untuk mengurangi fluktuasi data yang berlebih. Dengan menggunakan rasio ini, nilai miliar bahkan triliun akan disederhanakan, tanpa mengubah proporsi dan nilai aset sebenarnya.

\section{Profitabilitas}

Menurut Agus Sartono (2012) menyatakan bahwa profitabilitas adalah kemampuan memperoleh laba yang maksimal selama periode tertentu dalam hubungannya dengan penjualan, total aktiva maupun modal sendiri perusahaan tersebut. Tujuam akhir yang ingin dicapai suatu perusahaan adalah memperoleh laba yang maksimal. Manajemen perusahaan dituntut harus mampu untuk memenuhi target yang telah ditetapkan. Rasio profitabilitas merupakan rasio untuk menilai kemampuan perusahaan dalam mencari laba. Hasil pengukuran tersebut dapat dijadikan alat evaluasi kinerja manajemen selama ini.

Tujuan penggunaan rasio profitabilitas adalah: (1) untuk mengukur laba yang diperoleh perusahaan dalam satu periode tertentu. (2) menilai posisi laba perusahaan tahun sebelumnya dengan tahun sekarang. (3) menilai perkembangan 
laba dari waktu ke waktu. (4) menilai besarnya laba bersih sesudah pajak dengan modal sendiri. (5) mengukur produktivitas dari seluruh dana perusahaan yang digunakan baik modal pinjaman maupun modal sendiri.

Menurut Undang-Undang No. 36 Tahun 2008 pasal 1 dijelaskan bahwa penghasilan yang diterima oleh subjek pajak akan dikenakan pajak penghasilan. Besar kecilnya pajak yang harus dibayarkan wajib pajak berbanding lurus dengan besar kecilnya penghasilan yang diperoleh wajib pajak dalam satu periode, sehingga semakin tinggi profitabilitas perusahaan maka semakin tinggi pajak yang harus dibayarkan sedangkan perusahaan yang memiliki tingkat keuntungan yang rendah atau bahkan mengalami rugi akan membayar pajak lebih sedikit atau tidak sama sekali.

Menurut Kasmir (2014) terdapat empat jenis utama yang digunakan dalam menilai tingkat profitabilitas, yaitu: (1) Gross Profit Margin/ Margin Laba Kotor, (2) Net Profit Margin/ Margin Laba Bersih), (3 Return On Equity, dan (4) Return On Asset. Margin Laba Kotor Merupakan rasio yang mengukur efisiensi operasi perusahaan dan juga pengendalian harga pokok penjualan. Semakin besar margin laba kotor semakin baik keadaan operasi perusahaan, karena hal ini menunjukkan bahwa harga pokok penjualan relatif rendah dibandingkan dengan penjualan. Margin laba bersih Merupakan rasio yang mengukur penjualan yang sudah dikurangi dengan seluruh biaya dan pengeluaran, termasuk bunga dan pajak.

Return On Equity Merupakan rasio yang mengukur sejauh mana kemampuan perusahaan memperoleh laba bersih setelah pajak dengan modal sendiri. Rasio ini mengukur tingkat keuntungan dari investasi yang telah dilakukan pemilik perusahaan. ROA merupakan rasio yang menunjukkan hasil atas jumlah aset yang digunakan dalam perusahaan. ROA juga merupakan suatu ukuran tentang efektivitas manajemen dalam mengelola investasinya. Semakin kecil rasio ini semakin kurang baik, dan sebaliknya.

\section{Leverage}

Menurut Kasmir (2014) leverage adalah rasio yang digunakan untuk mengukur sejauh mana perusahaan dibiayai dengan hutang. Artinya, berapa besar hutang yang ditanggung perusahaan dibandingkan dengan asetnya. Menurut Agus Sartono (2012) leverage adalah penggunaan aset dan sumber dana oleh perusahaan yang memiliki beban tetap dengan maksud agar meningkatkan keuntungan potensial pemegang saham. Perusahaan yang mempunyai leverage yang tinggi menunjukkan perusahaan tersebut banyak bergantung pada hutang dalam membiayai aset perusahaan. Hutang akan menyebabkan adanya beban bunga atas pinjaman tersebut yang dapat mengurangi penghasilan kena pajak perusahaan.

Tujuan perusahaan menggunakan rasio leverage menurut Kasmir (2014), diantaranya yaitu: (a) Perusahaan mengetahui posisi perusahaan terhadap kewajiban kepada pihak lainnya. (b) Untuk menilai kemampuan perusahaan dalam memenuhi kewajiban yang bersifat tetap (seperti angsuran pinjaman termasuk bunga). (c) Untuk menilai keseimbangan antara nilai aktiva khususnya aktiva tetap dan modal. (d) Untuk menilai seberapa besar aktiva perusahaan dibiayai oleh hutang. (e) Untuk menilai seberapa besar pengaruh hutang perusahaan terhadap pengelolaan aktiva. (f) Untuk menilai atau mengukur berapa bagian dari setiap rupiah modal sendiri yang dijadikan jaminan hutang jangka panjang. (g) Untuk menilai berapa dana

Jurnal Ilmiah Akuntansi dan Ekonomi Volume. 5 Nomor. 2, Agustus 2020 Hal. 91 
pinjaman yang segera akan ditagih, terdapat sekian kalinya modal sendiri yang dimiliki.

Menurut Kasmir (2014) rasio leverage secara umum adalah: (1) Debt to Total Asset Ratio/ DAR, (2) Debt to Equity Ratio/ DER, (3) Time Interest Earned/ TIE, (4) Fixed Charge Coverage Ratio, dan (5) Long-term Debt to Equity Ratio. DAR Merupakan rasio yang digunakan untuk mengukur perbandingan antara total hutang dengan total aktiva. Rasio DAR merupakan rasio yang digunakan untuk mengukur seberapa besar beban hutang yang harus ditanggung perusahaan dalam rangka pemenuhan aset, perusahaan dalam operasinya menggunakan sumber dana yang menimbulkan beban tetap bagi perusahaan.

DER merupakan rasio yang digunakan untuk menilai utang dengan ekuitas. Rasio ini dihitung dengan cara membandingkan antara seluruh utang terhadap seluruh ekuitas. Rasio ini berguna untuk mengetahui jumlah dana yang disediakan kreditor dengan pemilik perusahaan. Rasio ini berfungsi untuk mengetahui setiap rupiah modal sendiri yang dijadikan untuk jaminan utang. Bagi kreditur, semakin tinggi rasio ini maka akan semakin tidak menguntungkan karena akan semakin besar risiko yang ditanggung atas kegagalan yang mungkin terjadi di perusahaan. Namun, bagi perusahaan semakin besar rasio ini akan semakin baik. Sebaliknya, dengan rasio yang rendah, semakin tinggi tingkat pendanaan yang disediakan pemilik dan semakin besar batas pengamanan bagi peminjam jika terjadi kerugian atau penyusutan terhadap nilai aktiva. Perusahaan dengan arus kas yang stabil biasanya memiliki rasio yang lebih tinggi dari rasio kas yang kurang stabil. TIE Merupakan rasio yang digunakan untuk mengukur kemampuan perusahaan untuk membayar bunga, atau mengukur seberapa jauh pendapatan dapat berkurang tanpa perusahaan mengalami kesulitan keuangan karena tidak mampu membayar bunga. Rasio FCC mengukur seberapa besar kemampuan perusahaan untuk menutup beban tetapnya termasuk pembayaran deviden saham preferen, bunga, angsuran pinjaman dan sewa.

\section{Kualitas Audit}

Kualias audit dapat diukur berdasarkan ukuran Kantor Akuntan Publik (KAP) yang mengaudit laporan keuangan perusahaan (Mathius Tandiontong, 2015). Kualitas audit merupakan segala kemungkinan dimana auditor pada saat mengaudit laporan keuangan klien atau perusahaan dapat menemukan pelanggaran yang terjadi dalam sistem akuntansi klien dan melaporkannya dalam laporan keuangan auditan, dimana dalam melaksanakan tugasnya tersebut auditor mengikuti pedoman pada standar auditing dan kode etik akuntan publik yang relevan.

Laporan keuangan yang diaudit oleh auditor KAP The Big Four menurut beberapa referensi lebih berkualitas karena lebih mampu membatasi praktik manajemen laba sehingga menampilkan nilai perusahaan yang sebenarnya, oleh karena itu diduga perusahaan yang diaudit oleh KAP The Big Four memiliki tingkat kecurangan yang lebih rendah dibandingkan dengan perusahaan yang diaudit KAP Non The Big Four (Nuralifmida Ayu Annisa dan Lulus Kurniasih 2012 dalam Fitri dan Tridahus, 2015). 


\section{METODOLOGI PENELITIAN}

\section{Waktu dan Tempat Penelitian}

Penelitian ini dilakukan selama 4 bulan yaitu dimulai bulan April sampai dengan Juli 2020. Penelitian ini dilakukan pada Bursa Efek Indonesia (BEI) yang beralamat di Menara I J1. Sudirman Kav 52 -53 Jakarta Selatan 12190 Indonesia, dengan melalui website BEI yaitu www.idx.co.id

\section{Desain Penelitian}

Desain penelitian yang digunakan adalah penelitian kausal (causal research) yang merupakan penelitian untuk mengetahui pengaruh antara satu atau lebih variabel bebas terhadap variabel terikat.

\section{Variabel Penelitian}

Variabel yang digunakan dalam penelitian ini adalah sebagai berikut:

a. Variabel bebas atau independen yaitu ukuran perusahaan (X1), Profitabilitas (X2), Leverage (X3), dan kualitas audit (X4). Ukuran perusahaan diproksikan dengan Ln total aset. Profitabilitas diproksikan dengan ROA. ROA merupakan rasio yang menunjukkan seberapa besar kontribusi aset dalam menciptakan laba bersih. ROA dihitung dengan cara membagi laba bersih setelah dengan total aset. Leverage diproksikan DAR. Rasio DAR yang digunakan untuk mengukur perbandingan antara total hutang dengan total aktiva. Kualitas audit dapat diukur melalui Kantor Akuntan Publik (KAP) yang mengaudit laporan keuangan perusahaan. KAP yang berafiliasi dengan KAP The Big Four dan yang tidak berafiliasi dengan KAP The Big Four.

b. Variabel terikat atau dependen yaitu penghindaran pajak, yang diproksikan dengan CETR. CETR merupakan perbandingan antara pembayaran pajak dengan laba sebelum pajak.

\section{Jenis dan Sumber Data}

Penelitian ini menggunakan data sekunder, yaitu data yang diperoleh dari pihak lain atau data yang telah tersedia. Data tersebut (laporan keuangan) diperoleh dari website Bursa Efek Indonesia (www.idx.co.id).

\section{Populasi dan Sampel}

Dalam penelitian ini populasi yang digunakan yaitu perusahaan manufaktur yang terdaftar di Bursa Efek Indonesia periode 2016 - 2018, dan sampel dalam penelitian ini menggunakan metode Purposive Sampling. Adapun kriteria yang digunakan dalam penelitian ini adalah sebagai berikut : (1) Perusahaan manufaktur yang terdaftar di BEI pada periode tahun 2016 sampai dengan tahun 2018. (2) Perusahaan yang menyajikan data keuangan yang lengkap selama periode tahun 2016 sampai dengan tahun 2018. (3) Perusahaan yang menyajikan laporan keuangan tahunan yang dinyatakan rupiah. (4) Perusahaan yang memperoleh laba selama periode penelitian yaitu tahun 2015 sampai dengan tahun 2017 .

\section{Metode Analisis Data \\ Statistik Deskriptif}


Statistik deskriptif yaitu suatu teknik analisis data yang berusaha menjelaskan atau menggambarkan berbagai karakteristik data. Program yang digunakan untuk mengolah data adalah Statistical Product and Service Solution versi 22.00 .

\section{Analisis Regresi Logistik}

Pada penelitian ini menggunakan analisis regresi logistik (logistic regression). Regresi logistik digunakan apabila variabel dependennya adalah satu metrik dan variabel independennya lebih dari satu metrik dan non metrik. Pada teknik analisis regresi logitik tidak memerlukan lagi uji normalitas dan uji asumsi klasik pada variabel bebasnya.

Adapun model regresi logistic yang terbentuk adalah:

\section{Keterangan:}

$$
\mathrm{Y}=\beta 1 \mathrm{X} 1+\beta 2 \mathrm{X} 2+\beta 3 \mathrm{X} 3+\beta 4 \mathrm{X} 4+\varepsilon
$$

$$
\begin{array}{ll}
\mathrm{Y} & =\text { Penghindaran pajak } \\
\alpha & =\text { Konstanta } \\
\beta 1-\beta 4 & =\text { Koefisien regresi variabel independen } \\
\mathrm{X} 1 & =\text { Ukuran perusahaan } \\
\mathrm{X} 2 & =\text { Profitabilitas } \\
\mathrm{X} 3 & =\text { Leverage } \\
\mathrm{X} 4 & =\text { Kualitas audit } \\
\varepsilon & =\text { Error }
\end{array}
$$

Langkah-langkah dalam pengujian regresi logistic adalah sebagai berikut:

a. Menilai Keseluruhan Model (Overall Model Fit)

Langkah pertama adalah menilai Overall fit model terhadap data. Hipotesis untuk menilai model fit adalah sebagai berikut: (1) H0: Model yang dihipotesiskan fit dengan data, dan (2) HA: Model yang dihipotesiskan tidak fit dengan data. Hipotesis yang digunakan untuk menilai overall fit model adalah sebagai berikut: (a) Jika nilai -2 log Likelihood ada penurunan, maka H0 diterima, yang berarti bahwa model fit dengan data. (b) Jika nilai -2 log Likelihood tidak ada penurunan, maka $\mathrm{H} 0$ ditolak, yang berarti bahwa model tidak fit dengan data.

b. Koefisien Determinasi (Negelkerke $R$ square)

Koefisiensi determinasi digunakan untuk mengetahui seberapa jauh kemampuan model variabel independen (ukuran perusahaan, profitabilitas, leverage, dan kualitas audit) dalam menerangkan variasi variabel dependen (penghindaran pajak).

c. Menilai Kelayakan Model Regresi

Kelayakan model regresi dapat diuji dengan Hosmer and Lemeshow's Goodness of Fit Test. Model ini bertujuan untuk menguji hipotesis bahwa data empirik cocok atau sesuai dengan model. Hipotesis yang digunakan untuk menilai kelayakan model regresi adalah sebagai berikut: jika nilai Statistics Hosmer and Lemesho Goodness of Fit < 0,05 maka H0 ditolak, yang berarti bahwa model tidak dapat memprediksi nilai observasinya, dan sebaliknya.

d. Matriks Klasifikasi 
Matriks klasifikasi bertujuan untuk melihat presentasi estimasi perusahaan yang melakukan penghindaran pajak dan perusahaan tidak melakukan penghindaran pajak.

e. Omnibus Test

Pengujian pengaruh model secara simultan dalam penelitian ini menggunakan tabel Omnibus Tests of Model Coefficients. Uji ini mirip dengan uji F pada analisis regresi linier berganda.

Nilai uji ini dapat dilihat menggunakan p-value kemudian dibandingkan dengan nilai $\alpha$, dengan kriteria pengambilan keputusan sebagai berikut: (1) Jika $p$-value $>\alpha(0,05)$ maka variabel-variabel independen tidak berpengaruh secara simultan terhadap variabel dependen atau H0 diterima. Dan sebaliknya, (2) Jika $p$-value < $\alpha(0,05)$ maka variabel-variabel independen berpengaruh secara simultan terhadap variabel dependen atau $\mathrm{H} 0$ ditolak.

f. Pengujian Hipotesis Penelitian

Hipotesis dalam penelitian ini adalah untuk mengetahui pengaruh ukuran perusahaan, profitabilitas, leverage, dan kualitas audit terhadap penghindaran pajak.

Penentuan diterim atau tidaknya Ho didasarkan pada tingkat signifikan $\alpha=5 \%$ dengan kriteria sebagai berikut: (1) Jika nilai probabilitas ( $\operatorname{sig}$ ) > 0,05 maka H0 diterima, yang berarti bahwa variabel independen tidak berpengaruh terhadap variabel dependen. (2) Jika nilai probabilitas (sig) < 0,05 maka H0 ditolak, yang berarti bahwa variabel independen berpengaruh terhadap variabel dependen.

\section{ANALISIS HASIL DAN PEMBAHASAN}

\section{Statistik Deskriptif}

Pengolahan data ini menggunakan program Statistical Package for the Social Science (SPSS). Objek dalam penelitian ini adalah seluruh perusahaan manufaktur yang terdaftar di BEI periode 2016-2018 dengan total populasi sebanyak 153 perusahan manufaktur. Sampel dalam penelitian ini menggunakan teknik purposive sampling. Sampel yang memenuhi persyaratan sebanyak 72 perusahaan.

a. Ukuran perusahaan. Size diproksikan Ln Total Aset. Ukuran perusahaan mempunyai nilai minimum sebesar 25,22, nilai maksimum sebesar 34,09, nilai rata-rata (mean) sebesar 28,708, dan standar deviasi sebesar 1,72598. Total Aset paling rendah yaitu Primarindo Asia Infrastructure pada tahun 2017, nilai maksimum diperoleh dari total aset paling besar tahun 2016 yaitu Trisula Internasional.

b. Profitabilitas. Besarnya profitabilitas mempunyai nilai minimum sebesar 0,00 , nilai maksimum sebesar 0,53 , nilai rata-rata (mean) sebesar 0,0617 , dan standar deviasi sebesar 0,07739. Profitabilitas dengan nilai minimium Trisula Inernasional tahun 2016-2018., dan nilai maksimum Multi Bintang Indonesia tahun 2017.

c. Leverage. Besarnya Leverage mempunyai nilai minimum sebesar 0,00 , nilai maksimum sebesar 2, 06 , nilai rata-rata (mean) sebesar 0,4063, dan standar deviasi sebesar 0,25208.

Sampel perusahaan yang menggunakan KAP The Big Four sebanyak 82 
sampel atau sebesar 38\%. Sedangkan sampel yang menggunakan KAP Non The Big Four sebanyak 134 sampel atau sebesar 62\%. Dari jumlah total sampel sebanyak 216 perusahaan terdapat 79 perusahaan yang melakukan penghindaran pajak atau sebesar $36,6 \%$. Sedangkan untuk perusahaan yang tidak melakukan penghindaran pajak sebanyak 137 perusahaan atau sebesar $63,4 \%$.

\section{Analisis Regresi Logistik}

\section{Menilai Keseluruhan Model Fit (Overall Model Fit)}

Langkah pertama adalah menilai Overall fit model terhadap data. Uji ini bertujuan untuk mengetahui apakah model fit dengan data saat sebelum maupun sesudah variabel independen dimasukkan ke dalam model. Pengujian ini dilakukan dengan membandingkan nilai -2 log Likelihood awal (block 0 : Beginning Block) sebelum dimasukkannya variabel independen ke dalam model dengan nilai -2 log Likelihood akhir (block 1: Method = Enter) susudah variabel independen dimasukkan ke dalam model. Hipotesis yang digunakan untuk menilai overall fit model adalah sebagai berikut: (1) Jika nilai -2 log Likelihood ada penurunan, maka H0 diterima, yang berarti bahwa model fit dengan data. (2) Jika nilai -2 log Likelihood tidak ada penurunan, maka $\mathrm{H} 0$ ditolak, yang berarti bahwa model tidak fit dengan data.

Hasil pengujian model fit dapat dilihat pada tabel berikut:

\section{Tabel 1}

Overall Model Fit (Block 0 : Beginning Block)

\begin{tabular}{|c|c|c|c|}
\hline \multirow{2}{*}{\multicolumn{2}{|c|}{ Iteration }} & \multirow[b]{2}{*}{-2 Log likelihood } & Coefficients \\
\hline & & & Constant \\
\hline Step 0 & 1 & 283.682 & -.537 \\
\hline & 2 & 283.673 & -.551 \\
\hline & 3 & 283.673 & -.551 \\
\hline
\end{tabular}

Sumber: Data diolah, 2020

Tabel 2

Overall Model Fit (Block 1: Method = Enter)

\begin{tabular}{|c|c|c|c|c|c|c|}
\hline \multirow[b]{2}{*}{ Iteration } & \multirow{2}{*}{$\begin{array}{c}-2 \text { Log } \\
\text { likelihood }\end{array}$} & \multicolumn{5}{|c|}{ Coefficients } \\
\hline & & Constant & $\mathrm{X} 1$ & $\times 2$ & X3 & $X 4$ \\
\hline Step 1 & 272.625 & 4.939 & -3.276 & .739 & -.353 & .176 \\
\hline 2 & 271.652 & 6.409 & -4.084 & .966 & -.226 & .176 \\
\hline 3 & 271.578 & 7.094 & -4.478 & 1.026 & -.126 & .181 \\
\hline 4 & 271.578 & 7.161 & -4.517 & 1.032 & -.116 & .181 \\
\hline 5 & 271.578 & 7.161 & -4.517 & 1.032 & -.116 & .181 \\
\hline
\end{tabular}

Sumber: Data diolah, 2020 
Pada tabel 2 di atas dimana variabel independen tidak dimasukkan dalam model menunjukkan nilai -2 Log Likelihood awal sebesar 283,673. Pada tabel 2 pada saat variabel independen dimasukkan ke dalam model menunjukkan nilai -2 Log Likelihood akhir sebesar 271,578. Hal ini menunjukkan bahwa terdapat penurunan nilai -2 Log Likelihood yaitu sebesar 12,095. Penurunan nilai -2 Log Likelihood ini menunjukkan bahwa dengan memasukkan variabel independen ke dalam model dapat memperbaiki model fit serta menunjukkan model regresi yang lebih baik, yang berarti HO diterima, yang berarti bahwa model fit dengan data dan dapat melanjutkan proses pengujian selanjutnya

\section{Koefisien Determinasi (Nagelkere $R$ Square)}

Koefisiensi determinasi digunakan untuk mengetahui seberapa jauh kemampuan model variabel independen dalam menerangkan variasi variabel dependen. Pengujian ini bertujuan untuk mengetahui seberapa besar kombinasi variabel independen yaitu ukuran perusahaan, profitabilitas, leverage, dan kualitas audit mampu menerangkan variasi variabel yaitu penghindaran pajak. Dalam model regresi logistik besarnya koefisien determinasi ditunjukkan dengan nilai Nagelkere $R$ Square yang dapat diiterpretasikan seperti nilai $\mathrm{R}^{2}$ pada regresi berganda.

\section{Tabel 3}

Uji Koefisien Determinasi

\begin{tabular}{|l|r|r|r|}
\hline Step & -2 Log likelihood & Cox \& Snell R Square & Nagelkerke R Square \\
\hline 1 & 271.578 & .054 & .074 \\
\hline
\end{tabular}

Sumber: Data diolah, 2020

Pada tabel 3 di atas menunjukkan nilai Nagelkere $R$ Square yaitu sebesar 0,074 yang menunjukkan bahwa kemampuan variabel independen (ukuran perusahaan, profitabilitas, leverage, dan kualitas audit) dalam menjelaskan variabel dependen yaitu (penghindaran pajak sebesar 7,4\%), sedangkan sisanya sebesar $92,6 \%$ dijelaskan oleh variabel lain diluar penelitian ini.

\section{Menilai Kelayakan Model Regresi (Hosmer and Lemeshow's Goodness of Fit Test)}

Dalam menilai kelayakan model regresi dapat diuji menggunakan Hosmer and Lemeshow's Goodness of Fit Test. Model ini bertujuan untuk menguji hipotesis bahwa data empirik cocok atau sesuai dengan model (tidak ada perbedaan antar model dengan data sehingga model dapat dikatakan fit) (Ghozali, 2016).

Tabel 4

Kelayakan Model Regresi

\begin{tabular}{|l|r|r|r|}
\hline Step & Chi-square & Df & Sig. \\
\hline 1 & 12.454 & & .132 \\
\hline
\end{tabular}

Sumber: Data diolah, 2020

Berdasarkan tabel 4 di atas menunjukkan nilai signifikan dari output Hosmer and Lemeshow Test adalah 0,132 dimana lebih besar dari 0,05 maka $\mathrm{H}_{\mathrm{o}}$ diterima. Dengan hasil tersebut dapat disimpulkan bahwa model dapat memprediksi nilai observasinya atau dapat dikatakan model dapat diterima karena cocok dengan data observasinya. 


\section{Matriks Klasifikasi}

Matriks klasifikasi bertujuan untuk melihat presentasi estimasi perusahaan yang melakukan penghindaran pajak dan perusahaan tidak melakukan penghindaran pajak. Berdasarkan pengujian yang dilakukan. dapat disimpulkan bahwa dari 137 perusahaan yang tidak melakukan penghindaran pajak yang benarbenar tidak melakukan penghindaran pajak adalah 124 perusahaan dan 13 perusahaan melakukan penghindaran pajak, sehingga ketepatan klasifikasi yang didapatkan oleh kategori perusahaan yang tidak melakukan penghindaran pajak sebesar 90,5\%. Sedangkan dari 79 perusahaan yang melakukan penghindaran pajak yang benar-benar melakukan penghindaran pajak sebanyak 12 perusahaan dan 67 perusahaan tidak melakukan penghindaran pajak, sehingga untuk kategori perusahaan yang melakukan penghindaran pajak memperoleh ketepatan klasifikasi sebesar $15,2 \%$. Secara keseluruhan dapat dikatakan bahwa tingkat ketepatan klasifikasi sebesar $63 \%$.

\section{Omnibus Test}

Pengujian pengaruh model secara simultan dalam penelitian ini menggunakan tabel Omnibus Tests of Model Coefficients. Uji ini mirip dengan uji F pada analisis regresi linier berganda dimana untuk mengetahui pengaruh variabel bebas secara simultan terhadap variabel terikat. Berikut ini adalah tabelnya:

Tabel 5

Uji Secara Simultan

Omnibus Tests of Model Coefficients

\begin{tabular}{|c|c|c|}
\hline Chi-square & Df & Sig. \\
\hline 12.095 & 4 & .017 \\
12.095 & 4 & .017 \\
12.095 & 4 & .017 \\
\hline
\end{tabular}

Sumber: Data diolah, 2020

Dari hasil omnibus test menunjukkan bahwa nilai p-value sebesar 0,017 < 0,05 . Nilai $p$-value yang menunjukkan lebih kecil dari tingkat signifikansi sebesar 0,05, maka $\mathrm{H}_{0}$ ditolak yang berarti bahwa variabel independen berpengaruh simultan terhadap variabel dependen.

\section{Koefisien Regresi Logistik}

Pengujian hipotesis dalam penelitian ini bertujuan untuk mengetahui pengaruh ukuran perusahaan, profitabilitas, leverage, dan kualitas audit terhadap penghindaran pajak sebagai variabel dependen. Pengujian hipotesis ini dilakukan dengan menggunakan hasil uji regresi logistik yang ditujukkan dengan tabel hasil.

\section{Tabel 6}

Koefisien Regresi Model

Variables in the Equation

\begin{tabular}{|c|c|c|c|c|c|c|c|c|}
\hline & \multirow[b]{2}{*}{ B } & \multirow[b]{2}{*}{ S.E. } & \multirow[b]{2}{*}{ Wald } & \multirow[b]{2}{*}{ Df } & \multirow[b]{2}{*}{ Sig. } & \multirow[b]{2}{*}{$\operatorname{Exp}(B)$} & \multicolumn{2}{|c|}{ 95\% C.I.for EXP(B) } \\
\hline & & & & & & & Lower & Upper \\
\hline Step $1^{\mathrm{a}}$ X1 & -4.517 & 6.907 & .428 & 1 & .513 & .011 & .000 & 8267.949 \\
\hline
\end{tabular}




\begin{tabular}{|l|r|r|r|r|r|r|r|r|}
\hline $\mathrm{X} 2$ & 1.032 & .378 & 7.443 & 1 & .006 & 2.806 & 1.337 & 5.887 \\
$\mathrm{X} 3$ & -.116 & .563 & .043 & 1 & .836 & .890 & .296 & 2.681 \\
$\mathrm{X} 4$ & .181 & .362 & .250 & 1 & .617 & 1.199 & .589 & 2.439 \\
Constant & 7.161 & 9.981 & .515 & 1 & .473 & 1288.260 & & \\
\hline
\end{tabular}

Sumber: Data diolah, 2020

Dari hasil pengujian regresi logistik tersebut, maka persamaan regresinya adalah sebagai berikut:

$$
\begin{aligned}
Y= & 7.161-4.517(\text { Ukuran Perusahaan })+1.032 \text { (Profitabilitas) }-0,116 \text { (Leverage) } \\
& +0,181(\text { Kualitas Audit })+\varepsilon
\end{aligned}
$$

\section{Analisis Regresi Linier Berganda}

Berikut ini adalah tabel hasil analisis regresi linier berganda dengan bantuan SPSS. Berdasarkan tabel di bawah ini, maka dapat dibuat persamaan regresi linier berganda sebagai berikut :

$$
\mathrm{Y}=0,183+0,006 \mathrm{SIZE}+0,104 \mathrm{ROA}+0,076 \mathrm{DER}+\varepsilon
$$
berikut:

Berdasarkan persamaan regresi di atas, maka dijelaskan analisis sebagai

1. Nilai konstanta pada persamaan regresi di atas sebesar 7,161 artinya apabila variabel ukuran perusahaan, profitabilitas, leverage, dan kualitas audit bernilai nol (tidak ada) maka nilai penghindaran pajak sebesar 7,161.

2. Koefisien regresi variabel ukuran perusahaan sebesar $-4,517$. koefisien negatif menunjukkan setiap kenaikan ukuran perusahaan sebesar 1 (satu) poin maka penghindaran pajak akan mengalami penurunan sebesar -4,517.

3. Koefisien regresi variabel profitabilitas sebesar 1,032. koefisien positif menunjukkan setiap kenaikan profitabilitas sebesar 1 (satu) poin penghindaran pajak akan mengalami kenaikan sebesar 1,032.

4. Koefisien regresi variabel leverage sebesar -0,116. Koefisien negatif menunjukkan setiap kenaikan leverage sebesar 1 (satu) poin maka penghindaran pajak akan mengalami penurunan sebesar -0,116.

5. Koefisien regresi variabel kualitas audit sebesar 0,181. Koefisien negatif menunjukkan setiap kenaikan kualitas audit sebesar 1 (satu) poin maka penghindaran pajak akan mengalami kenaikan sebesar 0,181 .

Berdasarkan tabel analisis regresi logistik di atas, maka dapat dijelaskan mengenai pengaruh secara parsial masing-masing variabel independen sebagai berikut:

\section{a. Pengaruh Ukuran Perusahaan Size terhadap Penghindaran Pajak}

Hasil pengujian menunjukkan bahwa koefisien dari ukuran perusahaan sebesar $-4,517$ dengan tingkat signifikan sebesar 0,513. Tingkat signifikansi 0,513 > 0,05 memberi kesimpulan $\mathrm{H}_{01}$ diterima dan $\mathrm{H}_{a 1}$ ditolak, yang berarti bahwa ukuran perusahaan tidak berpengaruh terhadap penghindaran pajak. Hal ini menunjukan bahwa besar atau kecilnya ukuran perusahaan tidak mempengaruhi pihak manajemen untuk melakukan tindakan penghindaran pajak dikarenakan setiap perusahaan mempunyai kewajiban yang sama yaitu membayar pajak kepada negara terlepas dari besar atau kecilnya ukuran perusahaan. 
Hal ini didukung pula dengan data penelitian yaitu perusahaan Trisula Internasional tahun 2016 memiliki nilai ukuran perusahaan sebesar 34,09 dengan nilai CETR sebesar 0,42 sementara perusahaan Primarindo Asia Infrastructure tahun 2017 memiliki nilai ukuran perusahaan sebesar 25,22 dengan nilai CETR sebesar 0,80 .

Hasil penelitian ini didukung oleh penelitian Annisa (2017) yang menyatakan bahwa size tidak berpengaruh terhadap penghindaran pajak. Hal ini dikarenakan semakin besar ukuran suatu perusahaan maka semakin menjadi pusat perhatian dari pemerintah dan akan menimbulkan kecenderungan bagi para manajer perusahaan untuk berlaku patuh atau pasif dalam melakukan penghindaran perpajakan.

\section{b. Pengaruh profitabilitas terhadap penghindaran pajak}

Hasil pengujian menunjukkan bahwa koefisien dari ukuran perusahaan sebesar 1,032 dengan tingkat signifikan sebesar 0,006. Tingkat signifikansi 0,006 < 0,05 memberi kesimpulan H03 ditolak dan Ha3 diterima, yang berarti bahwa profitabilitas berpengaruh positif terhadap penghindaran pajak.

Profitabilitas yang tinggi menunjukkan bahwa perusahaan mampu mendapatkan laba yang maksimal. Semakin tinggi laba perusahaan maka semakin tinggi beban pajaknya. Perusahaan yang memiliki profitabilitas tinggi memiliki kesempatan untuk memposisikan diri dalam tax planning yang mengurangi jumlah beban pajaknya, hal ini mendorong perusahaan untuk melakukan tindakan penghindaran pajak.

Dari hasil penelitian yang dilakukan oleh Ida Ayu Rosa Dewinta dan Putu Ery Setiawan (2016) bahwa ROA berpengaruh terhadap penghindaran pajak dikarenakan perusahaan mampu mengelola asetnya dengan baik salah satunya dengan memanfaatkan beban penyusutan atas pengeluaran untuk memperoleh harta tetap berwujud dan amortisasi atas pengeluaran untuk memperoleh harta tetap tidak berwujud yang mempunyai masa manfaat lebih dari satu tahun dapat digunakan sebagai pengurang laba kena pajak perusahaan.

\section{c. Pengaruh leverage terhadap penghindaran pajak}

Berdasarkan hasil pengujian hipotesis yang telah dilakukan, diperoleh hasil koefisien dari leverage sebesar -0,116 dengan tingkat signifikan sebesar 0,836. Tingkat signifikansi 0,836 > 0,05 memberi kesimpulan H03 diterima dan Ha3 ditolak, yang berarti bahwa leverage tidak berpengaruh terhadap penghindaran pajak. Hal ini menunjukan besar atau kecilnya hutang perusahaan tidak memiliki pengaruh terhadap penghindaran pajak.

Leverage pada perusahaan adalah tingkat dukungan modal perusahaan yang diperoleh dari pihak luar perusahaan. Semakin besar tingkat modal perusahaan maka akan semakin tinggi risiko yang akan dihadapi perusahaan seperti kebangkrutan dan biaya bunga yang tinggi.

Hasil penelitian ini didukung oleh penelitian (Tommy Kurniasih \& Maria M. Ratna Sari, 2013) Leverage tidak bepengaruh hal ini terjadi dikarenakan semakin tinggi tingkat hutang suatu perusahaan maka pihak manajemen akan lebih konservatif dalam melakukan pelaporan keuangan atau operasional perusahaan. Pihak manajemen akan lebih berhati-hati dan tidak akan mengambil resiko yang 
tinggi untuk melakukan aktivitas penghindaran pajak guna menekan beban pajaknya. Apabila hutang digunakan dalam jumlah yang besar maka dapat menimbulkan kerugian bagi perusahaan.

\section{d. Pengaruh kualitas audit terhadap penghindaran pajak}

Berdasarkan hasil pengujian hipotesis yang telah dilakukan, diperoleh hasil koefisien dari kualitas audit sebesar 0,181 dengan tingkat signifikan sebesar 0,617. Tingkat signifikansi 0,617 > 0,05 memberi kesimpulan H04 diterima dan Ha4 ditolak, yang berarti bahwa kualitas audit tidak berpengaruh terhadap penghindaran pajak.

Hal ini berarti kantor akuntan publik yang termasuk dalam The Big Four maupun Non The Big Four memiliki auditor-auditor yang professional dan kompeten dalam melakukan audit laporan keuangan perusahaan sehingga menghasilkan kualitas audit yang sama baiknya. Meskipun begitu, perusahaan yang diaudit oleh KAP The Big Four cenderung lebih dipercayai fiskus dibandingkan KAP Non The Big Four karena KAP The Big Four dianggap memiliki reputasi yang baik dan memiliki integritas yang tinggi. Kualitas audit tidak berpengaruh terhadap penghindaran pajak dikarenakan auditor KAP The Big Four maupun KAP Non The Big Four hanya sebatas mengaudit laporan keuangan tersebut dan tidak menemukan adanya pelanggaran dikarenakan memang penghindaran pajak bukanlah merupakan suatu pelanggaran namun sebuah upaya untuk pengurangan pajak secara legal dengan memanfaatkan celah-celah dari ketentuan perundangundangan perpajakan yang berlaku.

Hasil penelitian ini sesuai atau sejalan dengan penelitian yang dilakukan oleh Sri Mulyani (2018), Fitri Darmayanti dan Tridahus Susanto (2015). Sementara hasil penelitian ini tidak selaras dengan penelitian yang dilakukan Arry Eksandy (2017).

\section{Kesimpulan dan Saran \\ Kesimpulan}

Adapun kesimpulan dalam penelitian ini adalah sebagai berikut:

1. Ukuran perusahaan tidak berpengaruh terhadap penghindaran pajak.

2. Profitabilitas berpengaruh terhadap penghindaran pajak.

3. Leverage tidak berpengaruh terhadap penghindaran pajak.

4. Kualitas audit tidak berpengaruh terhadap penghindaran pajak.

\section{Saran}

Berdasarkan kesimpulan diatas, maka peneliti mengajukan beberapa saran yaitu sebagai berikut :

1. Bagi peneliti selanjutnya diharapkan untuk mempertimbangkan dalam penambahan variabel independen lain seperti umur perusahaan dan komite audit.

2. Penelitian selanjutnya diharapkan dapat lebih difokuskan pada sub sektor industri manufaktur yang terdaftar di Bursa Efek Indonesia. Memperpanjang periode waktu penelitian agar dapat memberikan gambaran yang lebih luas lagi mengenai pengaruhnya terhadap penghindaran pajak. 


\section{DAFTAR PUSTAKA}

Agus, Sartono. 2012. Manajemen Keuangan Teori dan Aplikasi. Edisi 4. Yogyakarta: BPFE.

Annisa. 2017. Pengaruh Return on Asset, Leverage, Ukuran Perusahaan dan Koneksi Politik Terhadap Penghindaran Pajak. JOM Fekon. Vol.4.No.1.Februari.2017.

Cahyono, Deddy Dyas. 2016. Pengaruh Komite Audit, Kepemilikan Institusional, Dewan Komisaris, Ukuran Perusahaan (Size), Leverage (DER) dan Profitabilitas (ROA) Terhdap Tindakan Penghindaran Pajak (Tax Avoidance) Pada Perusahaan Perbankan Yang Listing BEI Periode 2011-2013. Journal of Accounting Vlume 2 No.2. Maret 2016. Fakultas Ekonomika dn Bisnis Unpad.

Darmayanti, Fitri dan Susanto, Tridahus, 2015. Pengaruh Komite Audit, Kualitas Audit, Kepemilikan Institusional, Resiko Perusahaan, dan Return On Assets (ROA) Terhadap Tax Avoidance. Jurnal Bisnis dan Manajemen. Vol. 5, No. 2, Oktober, 2015.

Eksandy, Arry. 2017. Pengaruh Komisaris Independen, Komite Audit dan Kualitas Audit Terhadap Penghindaran Pajak (Tax Avoidance) (Studi Empiris Pada Sektor Industri Barang Konsumsi yang Terdaftar di Bursa Efek Indonesia Periode 2010-2014). Compotitive Journal Vol.1 No.1. Januari-Juni 2017. Fakultas Ekonomi dan Bisnis Universitas Muhammadiyah Tangerang.

Ghozali, Imam. 2016. Aplikasi Analisis Multivariate Dengan Program IBM SPSS. Semarang: Undip.

Hartono, Jogiyanto. 2013. Teori Portofolio dan Analisis Investasi Edisi 8. Yogyakarta: BPFE.

Kasmir. 2014. Analisis Laporan Keuangan, Edisi Pertama, Cetakan Ketujuh. Jakarta: Rajawali Persada.

Kasus penghindaran pajak Perusahaan Coco Cola Indonesia. 2014. https://ekonomi.kompas.com/read/2014/06/13/1135319/Coca.Cola.Diduga.A kali.Seto diakses pada 14 Februari 2020.

$\begin{array}{lllll}\text { Kementerian } & \text { Keuangan } & 2015 . & \text { Info } & \text { APBN }\end{array} 2015$. https://www.kemenkeu.go.id/apbn2015 diakses pada 14 Februari 2020.

Pohan, Chairil A. (2013). Manajemen Perpajakan. Jakarta: Gramedia Pustaka Utama.

Prawira, Yudi Mufti. 2016. Pengaruh Return On Assets, Corporate Governance, Ukuran Perusahaan Terhadap Tax Avoidance. Jurusan Akuntansi Fakultas Ekonomi Universitas Negeri Padang.

Suandy, Early. 2013. Perencanaan Pajak. Jakarta: Salemba Empat.

Sugiyono. 2016. Metode Penelitian Kuantitatif, Kualitataif dan R\&D. Bandung: Alfabeta.

Tandiontong, Mathius. 2015. Kualitas Audit dan Pengukurannya. Bandung: Alfabeta.

Undang-Undang Nomor 16 Tahun 2009 tentang Ketentuan Umum Perpajakan.

Undang-Undang No. 36 Tahun 2008 tentang pajak penghasilan.

Zain, Mohammad. 2007. Manajemen Perpajakan. Jakarta: Salemba Empat, Edisi 3.

Jurnal Ilmiah Akuntansi dan Ekonomi Volume. 5 Nomor. 2, Agustus 2020 Hal. 102 